ISSN 1392-3196 / e-ISSN 2335-8947

Zemdirbyste-Agriculture, vol. 105, No. 2 (2018), p. 149-158

DOI 10.13080/z-a.2018.105.019

\title{
Variation in productivity of Ipomoea batatas at various rates of nitrogen fertilization
}

\author{
Barbara SAWICKA ${ }^{1}$, Władysław MICHAŁEK ${ }^{1}$, Piotr PSZCZÓŁKOWSKI ${ }^{2}$, \\ Honorata DANILCENKO \\ ${ }^{1}$ University of Life Sciences in Lublin \\ Akademicka 15, 20-950 Lublin, Poland \\ E-mail: barbara.sawicka@up.lublin.pl \\ ${ }^{2}$ Variety Assessment Experimental Station of Research Centre for Cultivar Testing \\ Uhnin, 21-211 Dębowa Kłoda, Poland
}

${ }^{3}$ Aleksandras Stulginskis University

Studentų 11, Akademija, Kaunas distr., Lithuania

\begin{abstract}
Currently, the cultivation of sweet potato (Ipomoea batatas (L.) Lam.) is gaining more and more popularity. The aim of the present study was to investigate the effect of different nitrogen $(\mathrm{N})$ fertilization levels on the parameters related to the efficiency of the photosynthetic apparatus, plant photosynthetic productivity, tuber yield and tuber dry matter yield of $I$. batatas. The study also aimed to identify phenotypic variation in the physiological measures and tuber yield traits of I. batatas. To achieve these objectives, a field experiment was carried out during the period 2013-2015 in Uhnin $\left(51.5833^{\circ} \mathrm{N}, 23.0333^{\circ} \mathrm{E}\right)$, central-eastern Poland. The experimental factor was different nitrogen fertilization rates $\left(0,50,100,150\right.$ and $\left.200 \mathrm{~kg} \mathrm{ha}^{-1} \mathrm{~N}\right)$. The conditions in the experimental years had the strongest effect on tuber dry matter content and yield and on minimum chlorophyll fluorescence yield and chlorophyll $a$ content. The fertilization $\times$ year interaction had the lowest percentage contribution to the total variance, while its highest contribution was observed for chlorophyll $b$. Nitrogen fertilization had the lowest percentage contribution to the physiological measures of chlorophyll fluorescence, but a quite high contribution to tuber dry matter content and yield. Nitrogen fertilization up to a level of $150 \mathrm{~kg} \mathrm{ha}^{-1} \mathrm{~N}$ beneficially affected electron flow at successive plant growth stages, beginning from the 6-leaf stage until physiological maturity. Nitrogen fertilization was also shown to have a stimulating effect on the photosynthetic efficiency of I. batatas at the end of the growing season. A decreasing trend was observed in the maximum chlorophyll fluorescence yield $\left(\mathrm{F}_{\mathrm{m}}\right)$ as affected by increasing $\mathrm{N}$ rates. A significant increase in actual photochemical efficiency of photosystem (PS) II (Y) and in the photochemical fluorescence quenching coefficient (qP) was observed up to a level of $100 \mathrm{~kg} \mathrm{ha}^{-1} \mathrm{~N}$. The minimum chlorophyll fluorescence yield $\left(\mathrm{F}_{0}\right)$, non-photochemical fluorescence quenching coefficient $(\mathrm{qN})$ and electron transport rate (ETR) were most favourable in the plots fertilized at a rate of $150 \mathrm{~kg} \mathrm{ha}^{-1} \mathrm{~N}$.
\end{abstract}

Key words: chlorophyll, chlorophyll fluorescence, nitrogen nutrition, productivity, sweet potato.

\section{Introduction}

An important task of plant production is to seek plant species with the highest nutritional value and introduce them to cultivation. One of them is sweet potato (Ipomoea batatas (L.) Lam.), of the family Convolvulaceae, which is characterized by a high ability to bind solar energy and convert it into biomass. Tubers of this species can be valuable food both for humans and animals as well as an excellent raw material for food processing, pharmaceutical, distilling, chemical and power generation industries (Islam, 2006; Senanayake et al., 2013; Borawska-Jarmułowicz et al., 2014; Krochmal-Marczak et al., 2014). I. batatas has a remarkable ability to convert solar and soil energies into carbohydrates, giving impressive yields under marginal and stress situations and requires a minimum amount of agricultural inputs (Senanayake et al., 2013). Nonetheless, intensive cultivation technology may contribute to changes in their biological value by reducing the photosynthetic efficiency of plants (Sawicka et al., 2015). To determine the photosynthetic efficiency and physiological condition of photosynthesizing organisms, measurements of chlorophyll fluorescence are used. This is a phenomenon of re-emission of a part of absorbed light energy that causes excitation of chlorophyll molecules.

Please use the following format when citing the article:

Sawicka B., Michałek W., Pszczółkowski P., Danilcenko H. 2018. Variation in productivity of Ipomoea batatas at various rates of nitrogen fertilization. Zemdirbyste-Agriculture, 105 (2): 149-158 DOI 10.13080/z-a.2018.105.019 
The excited chlorophyll molecules return to the ground state through photochemical activity, fluorescence or heat. Fluorescence is measured on living leaves. Fluorescence measurement techniques find ever wider applications in agriculture where changes taking place in field crops at different stages of plant production can be monitored accurately. It is a universal and very quick method to estimate and determine the impact of various adverse environmental conditions on the efficient functioning of the photosynthetic apparatus. At the same time, in the opinion of Sawicka and Michałek (2005), Brestic and Zivcak (2013), Kalaji et al. (2014; 2016 a) and Živčák et al. $(2014 \mathrm{a} ; \mathrm{b} ; \mathrm{c})$, this technique allows the impact of a stressor to be diagnosed early, before stress symptoms occur, e.g., drought stress or elemental deficiency in the plants. Chlorophyll is excited by a light wave, not less than $620 \mathrm{~nm}$, which comes from the source of light in a fluorometer. The induced fluorescence of the leaf is received by a detector, also equipped with an appropriate filter that cuts off far-red fluorescence (Kalaji et al., 2016 b; Yooyongwech et al., 2017). The measurement is made in the absence of external light. This effect consists in a rapid rise in fluorescence after illumination for about $0.3 \mathrm{sec}$ and a slow decrease in its level ( $3 \mathrm{~min})$ until a steady-state level is reached. Fluorescence is expressed in arbitrary units. A slow decline in fluorescence is associated with increased carbon dioxide $\left(\mathrm{CO}_{2}\right)$ assimilation at the phase of biochemical photosynthesis. The shape of this curve allows us to determine the following fluorescence measures after adaptation in the dark: $\mathrm{F}_{0}, \mathrm{~F}_{\mathrm{m}}, \mathrm{F}_{\mathrm{v}}: \mathrm{F}_{\mathrm{m}}$, where $\mathrm{F}_{0}$ - minimal fluorescence, $\mathrm{F}_{\mathrm{m}}$ - maximal fluorescence, $\mathrm{F}_{\mathrm{v}}: \mathrm{F}_{\mathrm{m}}$ - maximum photochemical efficiency of PSII (Sawicka, Michałek, 2005; Brestic, Zivcak, 2013; Sawicka et al., 2015; Kalaji et al., 2016 a). So far, not all aspects of the I. batatas productivity have been known. Therefore, the paper focuses on the dependence of the effect of nitrogen fertilization on the photosynthetic efficiency and on the phenotypic variability of Ipomoea batatas.

\section{Materials and methods}

Field and laboratory investigations were carried out during the period 2013-2015 at an Experimental Station in Uhnin $\left(51.5833^{\circ} \mathrm{N}, 23.0333^{\circ} \mathrm{E}\right)$, central-eastern Poland. The experiment was set up in a randomized block design in three replicates on a fawn soil, produced from strong clay loam (WRB, 2014). The tested physical and chemical properties of soils are given in Table 1.

Table 1. Physical and chemical properties of soil in Uhnin, Poland (2013-2015)

\begin{tabular}{|c|c|c|c|c|c|c|c|c|c|c|}
\hline \multirow[t]{2}{*}{ Year } & \multicolumn{3}{|c|}{$\begin{array}{c}\text { Content of assimilable } \\
\text { macronutrients } \\
\mathrm{mg} \mathrm{kg}^{-1} \text { soil }\end{array}$} & \multirow{2}{*}{$\begin{array}{l}\text { Content of } \\
\text { humus } \\
\%\end{array}$} & \multirow{2}{*}{$\begin{array}{l}\mathrm{pH} \\
\mathrm{KCl}\end{array}$} & \multicolumn{5}{|c|}{$\begin{array}{l}\text { Content of micronutrients } \\
\qquad \mathrm{mg} \mathrm{kg}^{-1} \text { soil }\end{array}$} \\
\hline & $\mathrm{P}_{2} \mathrm{O}_{5}$ & $\mathrm{~K}_{2} \mathrm{O}$ & $\mathrm{Mg}$ & & & $\mathrm{Cu}$ & $\mathrm{Mn}$ & $\mathrm{Zn}$ & $\mathrm{Fe}$ & B \\
\hline 2013 & 202 & 131 & 79 & 0.94 & 5.98 & 6.62 & 316 & 40.3 & 3762 & 7.22 \\
\hline 2014 & 186 & 109 & 71 & 1.06 & 5.79 & 4.90 & 339 & 56.5 & 3922 & 5.30 \\
\hline 2015 & 241 & 118 & 61 & 1.03 & 6.66 & 8.98 & 165 & 41.2 & 3601 & 6.05 \\
\hline Average & 210 & 119 & 703 & 1.01 & 6.14 & 6.83 & 273 & 46.0 & 3762 & 6.19 \\
\hline
\end{tabular}

Note. Source of own experiment results, which made in the Laboratory Central of Agro-Ecological, the University of Life Sciences in Lublin.

Humus content was determined by the Tiurin method modified by Simakow (WójcikowskaKapusta, Niemczuk, 2006). The soil pH was determined potentiometrically. Analysis of macro- and microelements was performed using the atomic absorbtion spectrometry (ASS). The compost analysis was performed according to the following methods: dry mass, organic substance, $\mathrm{pH}$ and designation $\mathrm{N}$ - according to standard PN-Z-150113:2001 (Compost from municipal waste - Determination: $\mathrm{pH}$, organic content, organic carbon, nitrogen, phosphorus and potassium), designation $\mathrm{P}, \mathrm{K}, \mathrm{Ca}$ and $\mathrm{Mg}$ were determined by the standard PN-EN 13651:2002 (Soil improvers and growing media - Extraction of calcium chloride/DTPA (CAT) soluble nutrients). The mineral nitrogen was calculated according to the method provided by Fotyma et al. (2010).

The experimental factor consisted of nitrogen (N) fertilization rates: $0,50,100,150$ and $200 \mathrm{~kg} \mathrm{ha}^{-1}$, relative to uniform phosphorus and potassium fertilization ( $34 \mathrm{~kg} \mathrm{ha}^{-1} \mathrm{P}, 96 \mathrm{~kg} \mathrm{ha}^{-1} \mathrm{~K}$ ) and $30 \mathrm{tha}^{-1}$ of compost (white mustard + spring vetch + hay). The mineral composition of compost was as follows: dry matter $-502 \mathrm{~g}$, ash $-55.1 \mathrm{~g}$, total $\mathrm{N}-19.2 \mathrm{~g}$, mineral $\mathrm{N}-0.9 \mathrm{~g}$, phosphorus $(\mathrm{P})-3.2 \mathrm{~g}$, potassium $(\mathrm{K})-31.9 \mathrm{~g}$, magnesium $(\mathrm{Mg})-4.7 \mathrm{~g}$, sodium (Na) - $0.7 \mathrm{~g} \mathrm{~kg}^{-1}$; copper $(\mathrm{Cu})-0.42 \mathrm{mg}$, cadmium $(\mathrm{Ca})-$ $1.31 \mathrm{mg}$, chromium $(\mathrm{Cr})-15.4 \mathrm{mg}$, nickel $(\mathrm{Ni})-7.05 \mathrm{mg}$, zinc $(\mathrm{Zn})-35.7 \mathrm{mg}$, manganese $(\mathrm{Mn})-36.2$ and iron $(\mathrm{Fe})$
$-64.1 \mathrm{mg} \mathrm{kg}^{-1}$ dry mass of compost. Spring barley was the preceding crop for sweet potato.

Rooted cuttings of the sweet potato (Ipomoea batatas (L.) Lam.) Guinean cultivar 'Canuana', obtained by in vitro micropropagation were the reproductive material.

The chlorophyll fluorescence measures were evaluated during plant growth. Measurements of leaf chlorophyll fluorescence induction were made with a fluorometer PAM-2000 (Walz GmbH, Germany) at the 6-leaf stage, 25-leaf stage, full flowering stage and processing maturity of $I$. batatas. For statistical calculations, the results from the full flowering stage were taken into account. The following physiological measures were determined: chlorophyll $a$ and $b$ content in leaf fresh matter; average photosynthetic leaf area, as well as the following chlorophyll fluorescence parameters: minimum fluorescence $\left(\mathrm{F}_{0}\right)$, maximum fluorescence $\left(F_{m}\right)$ yield, maximum photochemical efficiency of PSII $\left(F_{v}^{m}: F_{m}\right)$, actual photochemical efficiency of PSII (Y), electron transport rate (ETR) in the PSII reaction centre, photochemical fluorescence quenching coefficient (qP) andnon-photochemicalfluorescencequenchingcoefficient (qN). All fluorescence measurements were carried out on the $3^{\text {rd }}$ true leaf, in 5 replicates. For measurement of physiological indicators, clip 2030-B (Walz GmbH) was used and light emission $650 \mathrm{~nm}$ and a standard 
intensity of $0.15 \mu \mathrm{mol} \mathrm{m} \mathrm{m}^{-2} \mathrm{~s}^{-1}$ PAR (photosynthetically active radiation) were used. The dark adaptation lasted 20 minutes. Chlorophyll $a$ and $b$ content in fresh leaf matter was determined spectrophotometrically according to Lichtenthaler and Wellburn (1983) on ten randomly selected leaves sampled from plants from the particular fertilization treatments (Gitelson et al., 2003). Depending on when autumn frosts occurred, I. batatas tubers were harvested on 15 September, 2013, 25 September, 2014 and 8 September, 2015. After harvest, the following traits were determined: tuber yield, tuber dry matter content - by the drying method, and tuber dry matter yield as the resultant of the tuber yield and the tuber dry matter content.

The results were statistically analysed by analysis of variance $(A N O V A)$ and regression analysis. The significance of the sources of variation was tested by the Fisher-Snedecor $F$-test: * - significant at $p_{005}$, ** - significant at $p_{0.01}, \mathrm{~ns}-$ not significant at $p_{0.05}$. The function parameters were determined by the least-squares method. To determine the percentage contributions of the individual sources of variation and their interactions to the total variation of the investigated traits, estimation of variance components was performed, where: $\sigma_{e}^{2}$ estimation of environmental variation associated with the repeating of observations or measurements over time, $\sigma_{N}^{2}$ - estimation of fertilizer variation and $\sigma_{\mathrm{p}}^{2}-$ estimation of (total) phenotypic variation. The empirical values of the least squares obtained from the variance analysis were compared to their predicted values. The variance components of the individual sources of variation were estimated. The correlations between the derived estimations of the variance components and their percentage structure formed the basis for evaluation of the effects of the fertilizer and year factors on the variation of the investigated traits. Taking into account the calculated estimations of the variance components, their percentage structure was calculated. Coefficients of variation of the studied traits, which are a measure of dispersion of the results, were also calculated using software $S A S$ (SAS Institute Inc., 2008). The relationships of tuber yield, tuber dry matter content and dry matter yield with the physiological measures were examined by simple regression and multiple stepwise regression.

The obtained results were analysed statistically by means of $A N O V A$, simple correlation and polynomial regression. A stepwise, progressive construction of the regression model was applied. It consisted in the fact that in the first step, the explanatory variable was selected for the model, which was most strongly correlated with the explained variable, and a model with significant parameters was determined. In the second step, another explanatory variable was chosen, the values of which were strongly correlated with the rest of the first step, and the extended model was characterized by the significance of all parameters. The model was adjusted to the empirical data by verifying the hypothesis about the significance of the determination coefficient. The procedure was terminated when the explanatory variables were missing or the inclusion of a new variable into the equation led to the loss of the significance value by parameters or the coefficient of determination. The significance of the sources of variability was tested by the Fischer-Snedecor $F$-test, and the significance of the differences between the averages compared was made using multiple Tukey intervals. Function parameters were determined by the least squares method and significance was verified by Student's $t$-test. In statistical calculations, I. batatas tuber yield served as the dependent variable: $y_{1}$ - total yield of tubers, $y_{2}$ - tuber dry matter content, $y_{3}$ - tuber dry matter yield, while the independent variables were the following: $x_{1}$ - nitrogen fertilization, $x_{2}-$ minimum chlorophyll fluorescence yield $\left(\mathrm{F}_{0}\right), x_{3}-$ maximum chlorophyll fluorescence yield $\left(\mathrm{F}_{\mathrm{m}}\right), x_{4}-$ maximum photochemical efficiency of photosystem (PS) II ( $\left.\mathrm{F}_{\mathrm{v}}: \mathrm{F}_{\mathrm{m}}\right)$, $x_{5}$ - actual photochemical efficiency of PSII (Y), $x_{6}$ - photochemical fluorescence quenching coefficient (qP), $x_{7}$ - non-photochemical fluorescence quenching coefficient (qN) and $x_{8}$ - electron transport rate (ETR). The variation in the analysed results was characterized by the following: arithmetic mean, standard deviation and variability coefficients $\mathrm{V}=\frac{S}{x} \times 100$, where $s$ is standard deviation, $x$ - arithmetic mean (software SPSS) (Table 2).

Based on the simple regression coefficients, variables were selected for multiple linear regression. The explanatory variables in the equations included in the paper are called the independent variables, whereas the explained variable - the dependent variable using software $S A S$.

The weather conditions varied throughout the study period. The year 2013 was in terms of rainfall fairly humid, but June and September were characterized by significantly excessive rainfall (Skowera et al., 2014); the year 2014 was fairly dry, whereas the year 2015 was optimal in terms of rainfall and air temperature (Table 3 ).

Table 2. Statistical characteristics of the dependent $(y)$ and independent $(x)$ variables

\begin{tabular}{|c|c|c|c|}
\hline Specification & Mean & $\begin{array}{l}\text { Standard } \\
\text { deviation }\end{array}$ & $\begin{array}{c}\text { Variability coefficient } \\
\%\end{array}$ \\
\hline \multicolumn{4}{|c|}{ Dependent variables $(y)$} \\
\hline Tuber yield $\mathrm{t} \mathrm{ha}^{-1}$ & 36.90 & 9.580 & 26.02 \\
\hline Dry matter content $\%$ & 25.40 & 2.303 & 9.104 \\
\hline Dry matter yield t ha-1 & 9.464 & 2.897 & 30.59 \\
\hline \multicolumn{4}{|c|}{ Independent variables $(x)$} \\
\hline Average photosynthetic leaf area $\mathrm{dm}^{-2}$ & 0.180 & 0.081 & 46.82 \\
\hline Chlorophyll $a$ & 0.650 & 0.169 & 26.46 \\
\hline Chlorophyll $b$ & 0.220 & 0.032 & 13.98 \\
\hline Minimum fluorescence yield $\left(\mathrm{F}_{0}\right)$ & 0.264 & 0.045 & 17.34 \\
\hline Maximum fluorescence yield $\left(\mathrm{F}_{\mathrm{m}}\right)$ & 1.280 & 0.207 & 16.16 \\
\hline Maximum photochemical efficiency of PSII $\left(\mathrm{F}_{\mathrm{v}}: \mathrm{F}_{\mathrm{m}}\right)$ & 0.607 & 0.051 & 7.900 \\
\hline Actual photochemical efficiency of PSII (Y) & 0.487 & 0.067 & 13.65 \\
\hline Photochemical fluorescence quenching coefficient (qP) & 0.578 & 0.059 & 10.16 \\
\hline Non-photochemical fluorescence quenching coefficient (qN) & 0.146 & 0.045 & 30.80 \\
\hline Electron transport rate (ETR) & 23.97 & 3.852 & 16.07 \\
\hline
\end{tabular}


Table 3. Total rainfall and average of air temperature during the growing season of Ipomoea batatas, the data from the meteorological station in Uhnin, Poland (2015-2017)

\begin{tabular}{|c|c|c|c|c|c|}
\hline Year & Month & $\begin{array}{c}\text { Rainfall } \\
\mathrm{mm}\end{array}$ & $\begin{array}{c}\text { Temperature } \\
{ }^{\circ} \mathrm{C}\end{array}$ & $\begin{array}{l}\text { Hydrothermal } \\
\text { coefficient } \\
\text { of Sielianinov }\end{array}$ & $\begin{array}{l}\text { Classification of the month } \\
\text { according to Sielianinov } \\
\text { in the modification of Skowera }\end{array}$ \\
\hline \multirow{7}{*}{2013} & April & 61.8 & 8.8 & 2.3 & wet \\
\hline & May & 46.7 & 12.8 & 3.0 & very humid \\
\hline & June & 120.3 & 16.7 & 0.9 & dry \\
\hline & July & 45.2 & 19.4 & 0.8 & dry \\
\hline & August & 6.1 & 21.4 & 0.1 & extremely dry \\
\hline & September & 130.2 & 15.5 & 2.8 & very humid \\
\hline & Total & 410.3 & & & fairly humid \\
\hline \multirow{7}{*}{2014} & April & 47.1 & 10.0 & 1.6 & optimum \\
\hline & May & 46.3 & 15.3 & 1.0 & dry \\
\hline & June & 87.3 & 19.1 & 1.5 & optimum \\
\hline & July & 114.1 & 20.5 & 1.8 & fairly humid \\
\hline & August & 41.0 & 19.5 & 0.7 & very dry \\
\hline & September & 11.8 & 15.5 & 0.3 & extremely dry \\
\hline & Total & 347.6 & & & fairly dry \\
\hline \multirow{7}{*}{2015} & April & 51.8 & 8.1 & 2.1 & wet \\
\hline & May & 65.5 & 13.7 & 1.5 & optimum \\
\hline & June & 23.1 & 18.3 & 0.4 & extremely dry \\
\hline & July & 132.0 & 19.4 & 2.2 & wet \\
\hline & August & 27.0 & 20.3 & 0.4 & extremely dry \\
\hline & September & 83.3 & 14.8 & 1.9 & fairly humid \\
\hline & Total & 382.7 & & & Optimal \\
\hline
\end{tabular}

Note. Ranges of values of this index were classified according to Sielianinov in the modification of Skowera et al. (2014) as: extremely dry $-\mathrm{k} \leq 0.4$, very dry $-0.4<\mathrm{k} \leq 0,7$, dry $-0.7<\mathrm{k} \leq 1.0$, fairly dry $-1.0<\mathrm{k} \leq 1.3$, optimum $-1.3<\mathrm{k} \leq 1.6$, fairly humid $-1.6<\mathrm{k} \leq 2.0$, wet $-2.0<\mathrm{k} \leq 2.5$, very humid $-2.5<\mathrm{k} \leq 3.0$. extremely humid $-\mathrm{k}>3.0$.

\section{Results}

All the physiological measures determined for I. batatas plants were significantly dependent on year, nitrogen fertilization, and the fertilization and year interaction. The effect of fertilization was significant for chlorophyll $a$ and chlorophyll $b$ content, maximum chlorophyll fluorescence yield $\left(\mathrm{F}_{\mathrm{m}}\right)$, actual photochemical efficiency of PSII (Y), photochemical fluorescence quenching coefficient (qP), non-photochemical fluorescence quenching coefficient $(\mathrm{qN})$ and electron transport rate (ETR).

Calculation of the percentage contribution of the variance to the total variance for the individual factors and their interactions allowed us to conclude that habitat conditions during the study period proved to be the factor that mostly determined the variation in the physiological measures of I. batatas (Table 4). They had the lowest contribution in the case of actual photochemical efficiency of PSII (28.5\%) and the highest contribution in the case of average photosynthetic leaf area $(82.8 \%)$. The fertilizer factor had the lowest contribution to the determination of the physiological measures of chlorophyll fluorescence; its percentage contribution ranged from $0.9 \%$ in the case of maximum photochemical efficiency of PSII to $29.5 \%$ in the case of actual photochemical efficiency of PSII (Y). The percentage contribution of the year $\times$ fertilization interaction to the variation in the physiological measures ranged from $4.3 \%$ in the case of average photosynthetic leaf area to $50.1 \%$ in the case of chlorophyll $b$ (Table 4 ).

Tuber yield, tuber dry matter content and tuber dry matter yield proved to be significantly dependent on fertilization, year, and the fertilization and year

Table 4. Effect of fertilization and year on photosynthetic leaf area, chlorophyll content and some measures of chlorophyll fluorescence in leaves of Ipomoea batatas and their percentage contribution to the total variance

\begin{tabular}{lcccccc}
\hline \multirow{2}{*}{ Specification } & \multicolumn{3}{c}{ Significance of effect } & \multicolumn{3}{c}{$\begin{array}{c}\text { Percentage contribution } \\
\text { of the variance to the total variance }\end{array}$} \\
\cline { 2 - 7 } & year & fertilization & fertilization $\times$ year & year & fertilization & fertilization $\times$ year \\
\hline $\mathrm{P}$ & $* *$ & $* *$ & $*$ & 82.81 & 13.84 & 4.299 \\
Chlorophyll $a$ & $* *$ & $* *$ & $* *$ & 68.69 & 23.34 & 15.72 \\
Chlorophyll $b$ & $* *$ & $* *$ & $* *$ & 39.62 & 10.09 & 50.11 \\
$\mathrm{~F}_{0}$ & $* *$ & $\mathrm{~ns}$ & $* *$ & 81.24 & 2.503 & 15.33 \\
$\mathrm{~F}_{\mathrm{m}}$ & $* *$ & $*$ & $* *$ & 80.43 & 5.401 & 22.71 \\
$\mathrm{~F}_{\mathrm{v}} \cdot \mathrm{F}_{\mathrm{m}}$ & $* *$ & $\mathrm{~ns}$ & $* *$ & 76.51 & 0.899 & 41.63 \\
$\mathrm{Y}$ & $* *$ & $* *$ & $* *$ & 28.48 & 29.52 & 45.29 \\
$\mathrm{qP}$ & $* *$ & $* *$ & $*$ & 41.02 & 14.11 & 44.81 \\
$\mathrm{qN}$ & $* *$ & $* *$ & $* *$ & 37.89 & 15.19 & 37.09 \\
$\mathrm{ETR}$ & $* *$ & $* *$ & $*$ & 60.14 & 2.72 & \\
\hline
\end{tabular}

$\mathrm{P}$ - average photosynthetic leaf area $\left(\mathrm{dm}^{-2}\right), \mathrm{F}_{0}-$ minimum fluorescence yield, $\mathrm{F}_{\mathrm{m}}$ - maximum fluorescence yield, $\mathrm{F}_{\mathrm{v}}: \mathrm{F}_{\mathrm{m}}-$ maximum photochemical efficiency of PSII, Y - actual photochemical efficiency of PSII, qP - photochemical fluorescence quenching coefficient, qN - non-photochemical fluorescence quenching coefficient, ETR - electron transport rate; $*_{-}$significant at $p_{0.05}, * *-$ significant at $p_{0.01}, \mathrm{~ns}-$ not significant at $p_{0.05}$ 
interaction. Year had the highest percentage contribution of the variance to the total variance for total tuber yield and tuber dry matter content $(61.3 \%$ and $41.3 \%$, respectively), whereas for tuber dry matter yield (45.2\%) the deciding factor was fertilization. The fertilization $\times$ year interaction had the lowest percentage contribution to the total variance in the case of tuber yield and tuber dry matter content ( $13.5 \%$ and $24.1 \%$, respectively), whereas the highest one - in the case of tuber dry matter yield $(32.4 \%)$ (Table 4$)$. At the flowering stage of I. batatas, the chlorophyll fluorescence parameters were significantly differentiated under the influence of nitrogen fertilization, and this applied to the following measures: $\mathrm{F}_{\mathrm{m}}, \mathrm{Y}, \mathrm{qP}$ and qN (Table 4).

The relationship between maximum efficiency of PSII in the dark and nitrogen fertilization is shown in the third degree regression equation, with $R^{2}=0.873^{* *}$, which means its high significance (Fig. 1). A decrease in the value of this measure was observed until a level of $150 \mathrm{~kg} \mathrm{ha}^{-1} \mathrm{~N}$.

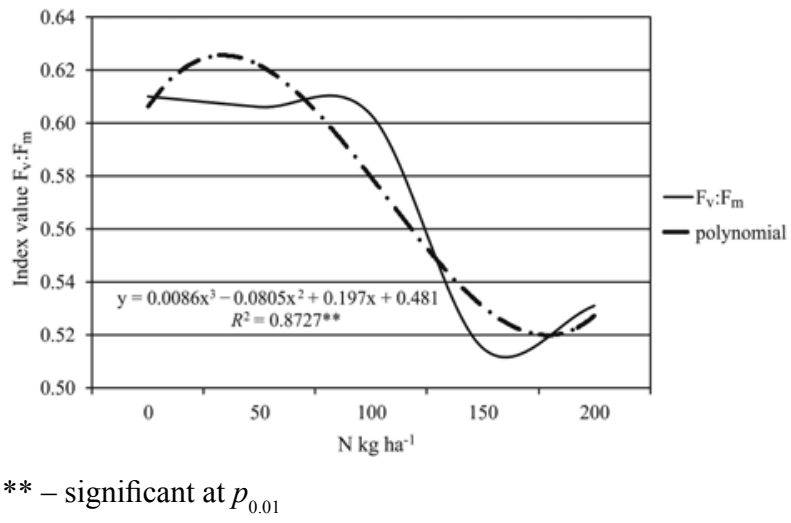

Figure 1. Dependence of maximum efficiency $\left(\mathrm{F}_{\mathrm{v}}: \mathrm{F}_{\mathrm{m}}\right)$ of photosystem (PS) II on nitrogen (N) fertilization at flowering stage of Ipomoea batatas

The PSII $\left(\mathrm{F}_{\mathrm{v}}: \mathrm{F}_{\mathrm{m}}\right)$ also significantly decreased under the influence of nitrogen fertilization, and its lowest value was found at a level of $150 \mathrm{~kg} \mathrm{ha}^{-1} \mathrm{~N}$. This is also confirmed by the third degree curvilinear regression equation, with a coefficient of determination $R^{2}=0.987 * *$ (Fig. 2).

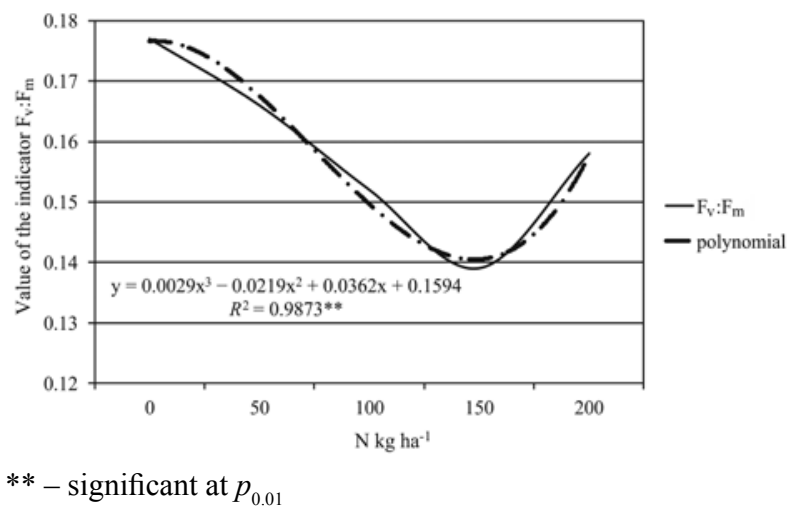

Figure 2. Dependence of efficiency of photosystem (PS) $\mathrm{II}$ in the light on nitrogen $(\mathrm{N})$ fertilization at flowering stage of Ipomoea batatas
The relationship between the actual number of electrons PSII, under conditions of adaptation to light, and nitrogen fertilization is shown in the third degree regression equation, with $R^{2}=0.954^{* *}$, which means very high reliability (Fig. 3 ).

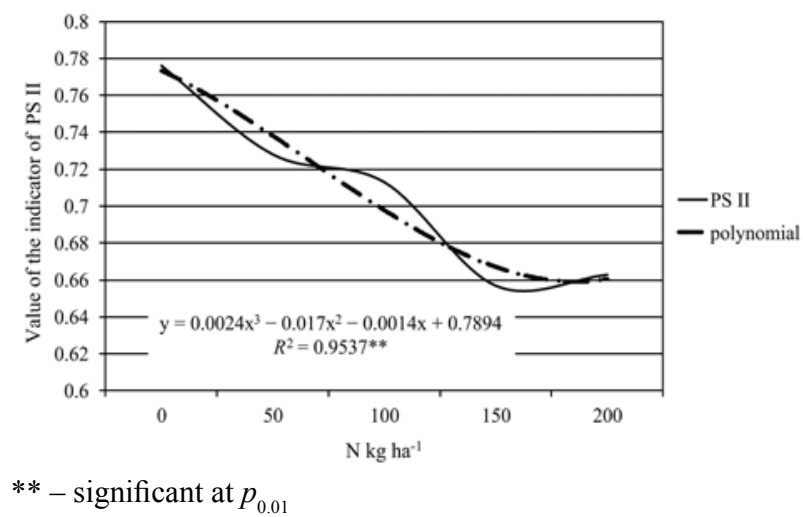

Figure 3. Dependence of the actual number of electrons in photosystem (PS) II under conditions of adaptation to light on nitrogen $(\mathrm{N})$ fertilization at flowering stage of Ipomoea batatas

A second degree parabolic relationship with nitrogen fertilization was observed in the case of the $\mathrm{qP}$, with a coefficient of determination $R^{2}=0.949 * *$ (Fig. 4). The regression equation shows that its lowest value was found in the plots fertilized at a rate of $152.3 \mathrm{~kg} \mathrm{ha}^{-1} \mathrm{~N}$.

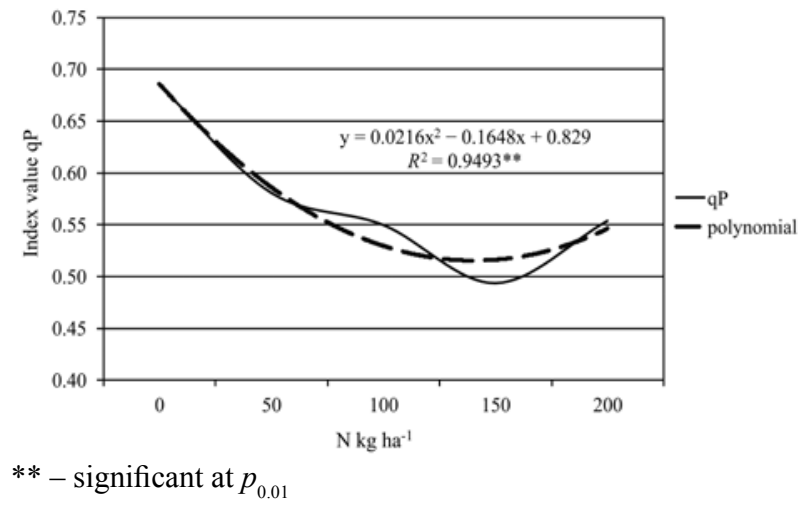

Figure 4. Dependence of the photochemical fluorescence quenching coefficient $(\mathrm{qP})$ on nitrogen $(\mathrm{N})$ fertilization of Ipomoea batatas

At the end of the growing season, on the other hand, the photochemical fluorescence quenching coefficient significantly increased under the influence of nitrogen fertilization up to a level of $150 \mathrm{~kg} \mathrm{ha}^{-1} \mathrm{~N}$. This is confirmed by the third degree curvilinear regression equation, with a coefficient of determination $R^{2}=0.953 * *$ (Fig. 5). Thus, the study results demonstrated nitrogen fertilization to have a stimulating effect on the photosynthetic efficiency of I. batatas at the end of the growing season, which evidences the positive action of $\mathrm{N}$ in the conversion of solar energy into chemical energy in PSII.

The effect of nitrogen fertilization on electron transport rate (ETR) at successive plant growth stages of I. batatas was beneficial up to a level of $150 \mathrm{~kg} \mathrm{ha}^{-1} \mathrm{~N}$. However, a further increase in $\mathrm{N}$ rate caused a significant decrease in the effectiveness of this nutrient and a decline in ETR (Fig. 6). 


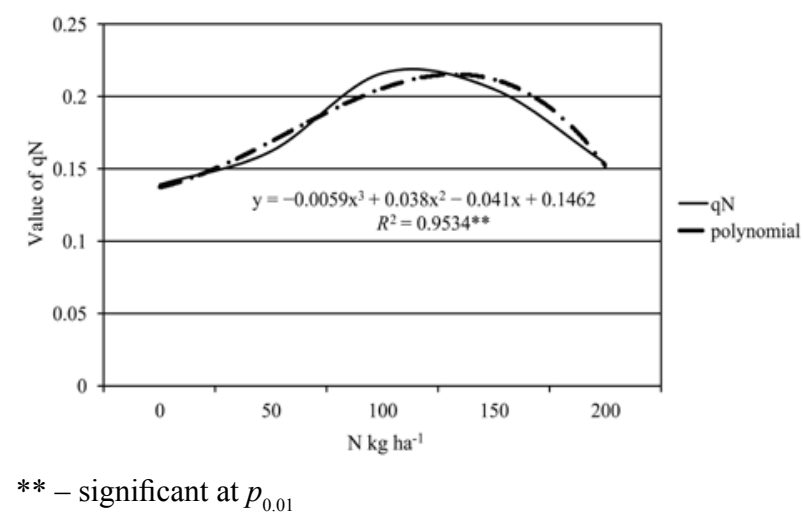

Figure 5. Dependence of the non-photochemical fluorescence quenching coefficient (qN) on nitrogen (N) fertilization at the end of Ipomoea batatas growing season

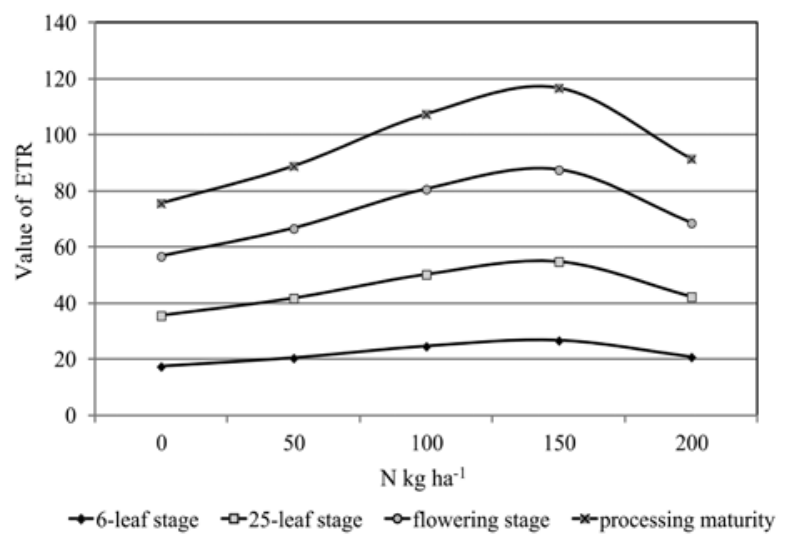

Figure 6. Effect of nitrogen $(\mathrm{N})$ fertilization on the value of electron transport rate $(\mathrm{ETR})$

The third degree polynomial regression equation confirmed that total yield was significantly dependent on nitrogen fertilization. Its highest value was found at a level of $150 \mathrm{~kg} \mathrm{ha}^{-1} \mathrm{~N}$. This is confirmed by the third degree curvilinear regression equation $y_{1}=-0.7058 \mathrm{x}^{3}+$ $4.6589 x^{2}-2.7852 x+25.77$ with a very high value of the coefficient of determination $\left(R^{2}=0.999 * *\right)$, where $y_{1}$ is dependent variable (total yield of tubers), $x-$ independent variable (nitrogen fertilization). Content of dry matter of tubers $\left(y_{2}\right)$ significantly increased up to a level of $100 \mathrm{~kg} \mathrm{ha}^{-1} \mathrm{~N}$ (Table 5), which is shown in the second degree regression equation $y_{2}=-0.7893 \mathrm{x}^{2}+$ $5.9347 \mathrm{x}+0.342$ with a coefficient of determination $\left(R^{2}=\right.$ $0.971 * *)$, where $y_{2}$ is dry matter, $x$ - nitrogen fertilization (Table 5).

Table 5. Effect of nitrogen (N) fertilization on total yield of Ipomoea batatas tubers, content and yield of dry matter (DM)

\begin{tabular}{cccc}
\hline $\begin{array}{c}\text { Dose } \mathrm{N} \\
\mathrm{kg} \mathrm{ha}^{-1}\end{array}$ & $\begin{array}{c}\text { Total yield } \\
\mathrm{t} \mathrm{ha}^{-1}\end{array}$ & $\begin{array}{c}\mathrm{DM} \\
\%\end{array}$ & $\begin{array}{c}\text { Yield of DM } \\
\mathrm{t} \mathrm{ha}^{-1}\end{array}$ \\
\hline 0 & 26.99 & 21.39 & 5.76 \\
50 & 32.98 & 25.60 & 8.39 \\
100 & 40.60 & 28.10 & 11.40 \\
150 & 43.79 & 26.62 & 11.64 \\
200 & 40.14 & 25.30 & 10.13 \\
\hline $\mathrm{HSD} p_{0.05}$ & 1.92 & 1.32 & 0.49 \\
\hline
\end{tabular}

HSD - honestly significant difference
An increase in the dry matter yield was only observed in the case of $\mathrm{N}$ fertilization up to a level of $100 \mathrm{~kg} \mathrm{ha}^{-1}$, whereas above this level there was a decrease in the value of this trait (Table 5). This is confirmed by the second degree curvilinear regression equation $y_{3}=-1.074 x^{2}+7.3297 x+15.23$ with a coefficient of determination $R^{2}=0.962 * *$, where $y_{3}$ is yield of dry matter, $x$ - nitrogen fertilization.

When analysing the correlations between the selected I. batatas traits and physiological measures, statistical characteristics were calculated for the dependent variables $(x)$ and independent variables $(y)$. Among the dependent variables, dry matter content showed the highest stability, among the independent variables that is, at maximum photochemical efficiency of PSII, while average photosynthetic leaf area proved to be the least stable trait.

Significantly positive correlation between tuber yield and nitrogen fertilization, of minimum chlorophyll fluorescence yield, of actual PSII photochemical efficiency (Y) and electron flow rate in chloropalastes and significantly negative with qP was found (Table 6). The dry mass of tubers proved to be positively related to nitrogen fertilization, minimum chlorophyll fluorescence yield $\left(\mathrm{F}_{0}\right)$, total photosynthetic yield, with the nonchemical fluorescence quenching factor $(\mathrm{qN})$ and the electron transport rate (RTR) in chloroplasts (Table 6). The dry matter yield was significantly positively correlated with nitrogen fertilization $(r=0.601), \mathrm{F}_{0}$, total photosynthetic yield, qN and ETR (Table 6).

The polynomial regression analysis showed the total tuber yield to be positively associated with nitrogen fertilization and minimal chlorophyll fluorescence yield $\left(\mathrm{F}_{0}\right)$, but negatively with photochemical fluorescence quenching coefficient $(\mathrm{qN})$. The increase in nitrogen fertilization and minimum chlorophyll fluorescence per unit, within the limits of the standard deviation from the arithmetic mean, influenced the change in total tuber yield about the values (Table 2). The estimated model explained almost $96.9 \%$ of the variability of dependent variable $\left(R^{2}=0.969 * *\right)$ (Table 7$)$. The increase in nitrogen fertilization and the current photochemical efficiency of PSII per unit, within the limits of the standard deviation from the arithmetic mean, influenced the change in the tuber dry matter content. The estimated model explained almost $81.7 \%$ of variability of dependent variable $\left(R^{2}=\right.$ $\left.0.817^{* *}\right)$. The yield of dry matter exhibited a positive relationship with nitrogen fertilization and with the actual rate of electron transport (this ratio can be compared to the rate of $\mathrm{CO}_{2}$ assimilation or oxygen release) per unit, within the standard deviation from the arithmetic mean. The estimated model explained almost $83.7 \%$ of variability of dependent variable $\left(R^{2}=0.837^{* *}\right)$ (Table 7). The coefficient of determination for these equations was very high, due to this; the determined functions of the regression equation were highly significant. The coefficient of determination of the systems of equations was fulfilled by the level of 0.60 postulated by Kranz and Royle (1978), which proves the credibility of the method used for calculations. 
Table 6. Values of Pearson's correlation coefficients

\begin{tabular}{|c|c|c|c|c|c|c|c|c|c|c|c|}
\hline & $x_{1}$ & $x_{2}$ & $x_{3}$ & $x_{4}$ & $x_{5}$ & $x_{6}$ & $x_{7}$ & $x_{8}$ & $y_{1}$ & $y_{2}$ & $y_{3}$ \\
\hline$x_{1}$ & 1.000 & & & & & & & & & & \\
\hline$x_{2}^{1}$ & 0.154 & 1.000 & & & & & & & & & \\
\hline$x_{3}^{2}$ & -0.020 & $0.865 * *$ & 1.000 & & & & & & & & \\
\hline$x_{4}$ & $0.240^{*}$ & $0.835 * *$ & $0.839 * *$ & 1.000 & & & & & & & \\
\hline$x_{5}^{4}$ & 0.063 & 0.054 & -0.343 & -0.025 & 1.000 & & & & & & \\
\hline$x_{6}$ & -0.043 & $0.229 *$ & 0.084 & $0.326^{*}$ & $0.617 * *$ & 1.000 & & & & & \\
\hline$x_{7}$ & $0.383 *$ & $0.612 * *$ & $0.624 * *$ & $0.709 * *$ & 0.018 & 0.140 & 1.000 & & & & \\
\hline$x_{8}$ & $0.561 * *$ & 0.225 & 0.006 & 0.285 & $0.443 * *$ & 0.102 & $0.568 * *$ & 1.000 & & & \\
\hline$y_{1}$ & $0.565 * *$ & 0.323 & -0.216 & -0.014 & $0.525 * *$ & $-0.469 * *$ & 0.168 & $0.531 * *$ & 1.000 & & \\
\hline$y_{2}$ & $0.558 * *$ & $0.374^{*}$ & 0.016 & 0.230 & $0.415 * *$ & 0.229 & $0.385^{*}$ & $0.798 * *$ & $0.489 * *$ & 1.000 & \\
\hline$y_{3}$ & $0.601 * *$ & $0.359 *$ & -0.176 & 0.035 & $0.539 * *$ & -0.026 & $0.331 *$ & $0.649 * *$ & $0.975 * *$ & $0.666^{* *}$ & 1.000 \\
\hline
\end{tabular}

$y_{1}-$ total yield of tubers, $y_{2}-$ tuber dry matter content, $y_{3}-$ tuber dry matter yield; $x_{1}-$ nitrogen fertilization, $x_{2}-$ minimum chlorophyll fluorescence yield $\left(\mathrm{F}_{0}\right), x_{3}$ - maximum chlorophyll fluorescence yield $\left(\mathrm{F}_{\mathrm{m}}\right), x_{4}$ - maximum photochemical efficiency of photosystem (PS) II $\left(\mathrm{F}_{\mathrm{v}}: \mathrm{F}_{\mathrm{m}}\right), x_{5}$ - actual photochemical efficiency of PSII (Y), $x_{6}$ - photochemical fluorescence quenching coefficient (qP), $x_{7}$ - non-photochemical fluorescence quenching coefficient (qN), $x_{8}$ - electron transport rate (ETR); * - significant at $p_{0.05}, * *$ - significant at $p_{0.01}$

Table 7. The values of partial regression coefficients of Ipomoea batatas tuber yield, dry matter (DM) content and DM yield at the level of significance $p \leq 0.05$ in relation to change of value of independent variables per unit

\begin{tabular}{lccc}
\hline \multicolumn{1}{c}{ Specification } & $\begin{array}{c}\text { Tuber } \\
\text { yield } \\
\left(y_{1}\right)\end{array}$ & $\begin{array}{c}\text { DM } \\
\text { content } \\
\left(y_{2}\right)\end{array}$ & $\begin{array}{c}\text { DM } \\
\text { yield } \\
\left(y_{3}\right)\end{array}$ \\
\hline (a) - intersection & 30.97 & 13.64 & -42.05 \\
Nitrogen fertilization $\left(x_{1}\right)$ & 0.037 & 0.006 & 0.130 \\
$\mathrm{~F}_{0}-$ minimum chlorophyll fluorescence $\left(x_{2}\right)$ & 144.1 & \\
qP - photochemical fluorescence quenching coefficient $\left(x_{3}\right)$ & -74.88 & 2.850 \\
ETR - electron transport rate $\left(x_{4}\right)$ & & \\
Y- actual photochemical efficiency of PSII $\left(x_{5}\right)$ & & \\
\hline Coefficient of determination $\left(R^{2}\right)$ & $0.969^{* *}$ & $0.817^{* *}$ & $0.837^{* *}$ \\
\hline$* *-$ significant at $p_{0.01}$ & &
\end{tabular}

\section{Discussion}

Most of the important characteristics of I. batatas are subject to high phenotypic variation depending on the effects of various environmental factors and genotype. The soil and climatic conditions during the study period mostly determined the values of the physiological measures of chlorophyll fluorescence as well as tuber yield potential, tuber dry matter content, and tuber dry matter yield. They determined most strongly photosynthetic leaf area, maximum chlorophyll fluorescence yield $\left(\mathrm{F}_{\mathrm{m}}\right)$ and maximum photochemical efficiency of PSII. Su et al. (2016) examined the dry matter content and tuber yield of 123 cultivars of $I$. batatas and found significant differences among cultivars and the share of variance of cultivars in total variance was estimated at $13.98 \%$ and $54.74 \%$, respectively. A study by Sawicka et al. (2015) reveals that these values are mostly modified by the interaction of environment and agronomic factors. The fertilizer factor had the smallest contribution to the determination of the physiological measures of chlorophyll fluorescence, and its percentage reached $29.5 \%$ of the total phenotypic variation. In the opinion of Khamis et al. (1990), a consequence of a too high level of nitrogen fertilization is photoinhibition of photosynthesis, which is mainly manifested in the destruction of the PSII reaction centre and slower electron transport in both photosystems. According to of Borawska-Jarmułowicz et al. (2014), the effect of nitrogen on plant photosynthesis also manifests itself in an increase in leaf area to a size at which mutual shading of leaf blades reduces the possibility to utilize solar energy. Živčák et al. (2014 a; c) suggest that $\mathrm{N}$ and $\mathrm{Mg}$ fertilization is responsible for an increase in chlorophyll content in the photosynthetic parts.

In terms of dry matter content and yield of dry matter, the optimum $\mathrm{N}$ rate was $100 \mathrm{~kg} \mathrm{ha}^{-1}$. KrochmalMarczak et al. (2014) obtained similar results under the conditions of central-eastern Poland. Most studies on fertilization of I. batatas relate to tropical and subtropical conditions. For example, in India, fertilization of I. batatas at a rate of $125 \mathrm{~kg} \mathrm{ha}^{-1} \mathrm{~N}$ is recommended (Pushpalatha et al., 2017). According to Liu et al. (2017), tuber dry matter content of $I$. batatas as affected by nitrogen increases from 70 to 90 days after planting. Results of Kingori et al. (2016) suggest that nitrogen fertilization influences the physiological status of the I. batatas plants, including leaf expansion ability, stomatal conductance and chlorophyll content. A study by Brestic and Zivcak (2013) and Yooyongwech et al. (2017) has revealed that photosynthesis is a metabolic process that is particularly sensitive to many stress factors. A frequent component of the so-called multistress is fertilizer stress which occurs when photosynthetic pigments absorb too much photosynthetically active radiation (PAR) energy in relation to the capacity to convert it into chemical energy during photosynthesis (Brestic, Zivcak, 2013). As reported by Aleksandrov et al. (2014) and Kalaji et al. (2014), deficiencies of N, P, K, Ca, Mn, S and Fe lead to the dysfunction of the photosynthetic apparatus by reducing the photochemical efficiency of PSII. 
Deficiency of each of the above-mentioned minerals causes a different response of the plant, but nitrogen is considered to be the main factor limiting plant growth and yield (Kalaji et al., 2016 a). This is due to the fact that this element is one of the main building blocks of the plant, including chlorophyll. Based on chlorophyll fluorescence measurements, it has been found that nitrogen deficiency substantially reduces the pool of electron acceptors in PSII and the activity of some photosynthesis-related enzymes, among others RuBisCO (Kalaji et al., 2016 a). Živčák et al. (2014 b; c) also drew similar conclusions on the basis of a study on the effect of nitrogen deficiency on chlorophyll fluorescence in wheat.

Sawicka and Michałek (2005) as well as Sawicka et al. (2015) have found that differences in photosynthesis efficiency may depend on both leaf inclination and leaf chlorophyll content. A low extinction coefficient allows more effective control of the transfer of solar energy through the leaf canopy. Vertical leaf inclination may be more favourable, especially under high radiation conditions, by minimizing the probability of photoinhibition and light penetration to the lower leaf layers and thereby maximizing wholecanopy photosynthesis (Dumbuya et al., 2016). Higher net assimilation rate (NAR) values in tropical and subtropical countries, compared to the thermal and humidity conditions in Poland, may be attributable to more efficient light capture by this genotype due to its more straightened morphogenetic profile (Sawicka et al., 2015; Dumbuya et al., 2016).

A higher dry matter yield was also found due to increased $\mathrm{N}$ supply in the I. batatas environment. The fertilization and environment interaction also significantly affected both dry matter content and yield. This may be associated with root system length (Borawska-Jarmułowicz et al., 2014). A longer root system can be advantageous in the case of drought stress in the deeper soil layers, as confirmed by the study Yooyongwech et al. (2017).

The high dependence of I. batatas productivity on environmental factors is due to the high climatic requirements of this species. For proper growth and development, this species requires a temperature of about $25-30^{\circ} \mathrm{C}$ (Su et al., 2016). During the period after planting, the optimum temperature for growth of I. batatas should be about $20^{\circ} \mathrm{C}$. The short growing season of I. batatas under the conditions of the central-eastern Poland, limited by the occurrence of late May and early September frosts and the lack of irrigation do not allow us to obtain such high tuber yields as in the USA or China. It has been proven that the cell plasma membranes of I. batatas leaves are more exposed to solar radiation than in the case of other crop species (Su et al., 2016; Liu et al., 2017). However, during plant growth humidity conditions are of particular importance. Krochmal-Marczak et al. (2014) obtained the highest $I$. batatas yields at annual rainfall levels of 850-900 mm. Dumbuya et al. (2016) argues that water stress, after the beginning of tuberization, affects tuber yield, but not tuber quality or growth.

The demonstrated positive relationship between dry matter and maximum chlorophyll fluorescence yield
$\left(\mathrm{F}_{\mathrm{m}}\right)$, and between dry matter yield and electron transport rate (ETR) are all evidence that this technique can be used to predict the yield potential of I. batatas and dry matter accumulation in tubers. Thus, analysis of chlorophyll fluorescence parameters may serve as a very accurate tool to study photosynthetic reactions under stress conditions and evaluate the effects of adverse environmental factors on plants, which is confirmed by the research results of Sawicka and Michałek (2005), Kuckenberg et al. (2009), Kalaji et al. (2014; 2016 b) and Sawicka et al. (2015). At the same time, this technique allows early diagnosis of the impact of a stress factor, before visible stress symptoms occur.

\section{Conclusions}

1. Soil and climate conditions of the experimental years had the strongest effect on sweet potato (Ipomoea batatas (L.) Lam.) tuber yield and dry matter content, while among the physiological measures they have influenced minimum chlorophyll fluorescence yield $\left(\mathrm{F}_{0}\right)$ and chlorophyll $a$ content.

2. Nitrogen $(\mathrm{N})$ fertilization had the strongest effect on I. batatas tuber dry matter yield and actual electron transport in photosystem (PS) II.

3. The interaction of fertilization and weather conditions during the study period most strongly affected chlorophyll $b$ content and electron transport in PSII.

4. Under the influence of increasing $\mathrm{N}$ rates, there was a decreasing trend in maximum chlorophyll fluorescence yield $\left(\mathrm{F}_{\mathrm{m}}\right)$.

5. A significant increase in actual photochemical efficiency of PSII (Y) and in the photochemical fluorescence quenching coefficient $(\mathrm{qP})$ was found in the plots fertilized at $100 \mathrm{~kg} \mathrm{ha}^{-1} \mathrm{~N}$.

6. Minimum chlorophyll fluorescence yield $\left(\mathrm{F}_{0}\right)$, non-photochemical fluorescence quenching coefficient (qN) and electron transport rate (ETR), near the PSII reaction centre were dependent on the $\mathrm{N}$ rates used. The most favourable values of these parameters for I. batatas were found in plants fertilized at $150 \mathrm{~kg} \mathrm{ha}^{-1} \mathrm{~N}$.

7. The highest fresh tuber yield of I. batatas was obtained in the treatments fertilized with $150 \mathrm{~kg} \mathrm{ha}^{-1} \mathrm{~N}$, but the highest dry mass of tubers and their yield was obtained in the fertilization treatments with $100 \mathrm{~kg} \mathrm{ha}^{-1} \mathrm{~N}$.

Received 11092017

Accepted 05032018

\section{References}

1. Aleksandrov V., Krasteva V., Paunov M., Chepisheva M., Kousmanova M., Kalaji M. H., Goltsev V. 2014. Deficiency of some nutrient elements in bean and maize plants analyzed by luminescent method. Bulgarian Journal of Agricultural Science, 20: 24-30.

2. Borawska-Jarmułowicz B., Mastalerczuk G., Pietkiewicz S., Kalaji M. H. 2014. Low temperature and hardening effects on photosynthetic apparatus efficiency and survival of forage grass varieties. Plant. Soil and Environment, 60: 177-183. https://doi.org/10.17221/57/2014-PSE

3. Brestic M., Zivcak M. 2013. PSII fluorescence techniques for measurement of drought and high temperature stress signal in crop plants: protocols and applications. Rout G. R., Das A. B. (eds). Molecular stress physiology of plants, chapter 4 , p. $87-131$

https://doi.org/10.1007/978-81-322-0807-5_4 
4. Dumbuya G., Sarkodie-Addo J., Daramy M. A., Jallo M. 2016. Growth and yield response of sweet potato to different tillage methods and phosphorus fertilizer rates in Ghana. Journal of Experimental Biology and Agricultural Sciences, 4 (5): 475-483. https://doi.org/10.18006/2016.4(5).475.483

5. Fotyma M., Kęsik K., Pietruch Cz. 2010. Mineral nitrogen in soils of Poland as an indicator of plant nitrogen requirements and soil water cleanness. Nawozy i Nawożenie (Fertilizers and Fertilizaton) 38: 5-83 (in Polish).

6. Gitelson A. A., Gritz Y., Merzlyak M. N. 2003. Relationships between leaf chlorophyll content and spectral reflectance and algorithms for non-destructive chlorophyll assessment in higher plant leaves. Journal of Plant Physiology, 160: 271-282.

https://doi.org/10.1078/0176-1617-00887

7. Islam S. 2006. Sweetpotato (Ipomoea batatas L.) leaf: its potential effect on human health and nutrition. Journal of Food Science, 71 (2): R13-R21. https://doi.org/10.1111/j.1365-2621.2006.tb08912.x

8. Kalaji M. H., Oukarroum A., Alexandrov V., Kouzmanova M., Brestic M., Zivcak M., Samborska I. A., Cetner M. D. Allakhverdiev S. I., Goltsev V. 2014. Identification of nutrient deficiency in maize and tomato plants by in vivo chlorophyll $a$ fluorescence measurements. Plant Physiology and Biochemistry, 81: 16-25. https://doi.org/10.1016/j.plaphy.2014.03.029

9. Kalaji H. M., Jajoo A., Oukarroum A., Brestic M., Zivcak M., Samborska I. A., Cetner M. D., Łukasik I., Goltsev V., Ladle R. J. 2016 (a). Chlorophyll $a$ fluorescence as a tool to monitor physiological status of plants under abiotic stress conditions. Acta Physiologiae Plantarum, 38: 102. https://doi.org/10.1007/s11738-016-2113-y

10. Kalaji H. M., Cetner M. D., Dąbrowski P., Samborska I. A., Łukasik I., Swoczyna T., Pietkiewicz S., Bąba W. 2016 (b). Chlorophyll fluorescence measurements in environmental studies. KOSMOS, 65 (2): 197-201.

11. Khamis S., Lamaze T., Lemoine Y., Foyer C. 1990. Adaptation of the photosynthetic apparatus in maize leaves as result of nitrogen limitation. Relationships between electron transport and carbon assimilation. Plant Physiology, 94: 1436-1443

https://doi.org/10.1104/pp.94.3.1436

12. Kingori G. G., Nyamori A. J., Isutsa K. D. 2016. Improving seed potato leaf area index, stomatal conductance and chlorophyll accumulation efficiency through irrigation water, nitrogen and phosphorus nutrient management Journal of Agricultural Studies, 4 (1): 127-141. https://doi.org/10.5296/jas.v4i1

13. Kranz J., Royle D. J. 1978. Perspectives in mathematical modelling of plant diseases epidemics. Scott P. R., Bainbridge A (eds). Plant disease epidemiology. Blackwell Scientific Publications, p. 111-120.

14. Krochmal-Marczak B., Sawicka B., Słupski J., Cybulak T., Paradowska K. 2014. Nutrition value of the sweet potato (Ipomoea batatas (L.) Lam) cultivated in south-eastern Polish conditions. International Journal of Agronomy and Agricultural Research, 4 (4): 169-178.

15. Kuckenberg J., Tartachnyk I., Noga G. 2009. Temporal and spatial changes of chlorophyll fluorescence as a basis for early and precise detection of leaf rust and powdery mildew infections in wheat leaves. Precision Agriculture, 10 (1): 34-44.

https://doi.org/10.1007/s11119-008-9082-0

16. Lichtenthaler H. K., Wellburn A. 1983. Determination of total carotenoids and chlorophylls $a$ and $b$ of leaf extracts in different solvents. Biochemical Society Transactions, 11 (5): 591-592.

https://doi.org/10.1042/bst0110591
17. Liu M., Zhang A., Chen X., Jin R., Li H., Tang Z. 2017. The effect of potassium deficiency on growth and physiology in sweet potato [Ipomoea batatas (L.) Lam.] during early growth. HortScience, 52 (7): 1020-1028.

https://doi.org/10.21273/HORTSCI12005-177

18. Pushpalatha M., Vaidya P. H., Adsul P. B. 2017. Effect of graded levels of nitrogen and potassium on yield and quality of sweet potato (Ipomoea batatas L.). International Journal of Current Microbiology and Applied Sciences, 6 (5): 1689-1696. https://doi.org/10.20546/ijcmas.2017.605.183

19. Sawicka B., Michałek W. 2005. Evaluation and productivity of Helianthus tuberosus L. in the conditions of CentralEast Poland. Electronic Journal of Polish Agricultural Universities, series: Horticulture, 8 (3): 42. http://www. ejpau.media.pl/volume8/issue3/art-42.html

20. Sawicka B., Michałek W., Pszczółkowski P. 2015. Dependence of chemical composition of potato (Solanum tuberosum L.) tubers on physiological measures. Zemdirbyste-Agriculture, 102 (1): 41-50 https://doi.org/10.13080/z-a.2015.102.005

21. Senanayake S., Ranaweera K. K. D. S., Bamunuarachchi A., Gunaratne A. 2013. Comparative analysis of trypsin inhibitor levels in sweet potato cultivars in Sri Lanka. Journal of the National Science Foundation of Sri Lanka, 42 (1): 63-69. https://doi.org/10.4038/jnsfsr.v42i1.6681

22. SkoweraB.,JędrszczykE.,KopcińskaJ.,Ambroszczyk A. M., Kołton A. 2014. The effects of hydrothermal conditions during vegetation period on fruit quality of processing tomatoes. Polish Journal of Environmental Studies, 23 (1): 195-202.

23. Su W., Liu Y., Lei J., Wang L., Chai S., Jiao C., Yang X. 2016. Phenotypic variation analysis of sweet potato germplasm resources from different agro-climate zones in the world. American Journal of Experimental Agriculture, 13 (6): 1-13.

24. Wójcikowska-Kapusta A., Niemczuk B. 2006. Effect of type of use on content of various magnesium and potassium forms in profiles of rendzinas. Acta Agrophysica, 8 (3): 765-771 (in Polish).

25. WRB. 2014. World reference database for soil resources. World soil resources reports No. 106. FAO, Rome, 192 p.

26. Yooyongwech S., Samphumphung Y., Tisaram R., Theerawitaya C., Cha-Um S. 2017. Physiological, morphological changes and storage root yield of sweet potato [Ipomoea batatas (L.) Lam.] under PEG-induced water stress. Notulae Botanicae Horti Agrobotanici ClujNapoca, 45 (1): 164-171. https://doi.org/10.15835/nbha45110651

27. Živčák M., Olšovská K., Slamka P., Galambošová J., Rataj V., Shao H. B., Brestič M. 2014 (a). Application of chlorophyll fluorescence performance indices to assess the wheat photosynthetic functions influenced by nitrogen deficiency. Plant Soil and Environment, 60 (5): 210-215. https://doi.org/10.17221/73/2014-PSE

28. Zivcak M., Brestic M., Kalaji H. M., Govidjee 2014 (b). Photosynthetic responses of sun- and shade-grown barley leaves to high light: is very lover PSII connectivity in shade leaves associated with protection against excess of light? Photosynthetic Research, 119 (3): 339-354. https://doi.org/10.1007/s11120-014-9969-8

29. Živčák M., Olšovská K., Slamka P., Galambošová J., Rataj V., Shao H.-B., Kalaji M. H., Brestič M. 2014 (c). Measurements of chlorophyll fluorescence in different leaf positions may detect nitrogen deficiency in wheat. Zemdirbyste-Agriculture, 101 (4): 437-444. https://doi.org/10.13080/z-a.2014.101.056 
ISSN 1392-3196 / e-ISSN 2335-8947

Zemdirbyste-Agriculture, vol. 105, No. 2 (2018), p. 149-158

DOI $10.13080 / \mathrm{z}-\mathrm{a} .2018 .105 .019$

\title{
Saldžiųu bu bulvių produktyvumo pokyčiai priklausomai nuo tręšimo azoto trąšomis
}

\author{
B. Sawicka ${ }^{1}$, W. Michałek ${ }^{1}$, P. Pszczółkowski ${ }^{2}$, H. Danilcenko ${ }^{3}$ \\ ${ }^{1}$ Liublino gyvybès mokslų universitetas, Lenkija \\ ${ }^{2}$ Lenkijos augalų veislių tyrimo centro Veislių vertinimo bandymų stotis \\ ${ }^{3}$ Aleksandro Stulginskio universitetas, Lietuva
}

\section{Santrauka}

Šiuo metu vis labiau populiarèja saldžiujų bulvių auginimas. Tyrimo tikslas - ištirti tręšimo ịvairiomis normomis azoto (N) trąšų įtaką augalų fotosintezès efektyvumui, fotosintetiniam našumui, stiebagumbių derlingumui, baltymų ir sausųjų medžiagų kiekiui. Buvo tirti saldžiosios bulvès (Ipomoea batatas (L.) Lam.) augalų stiebagumbių derlingumo fiziologiniai ir fenotipiniai pokyčiai. Lauko eksperimentas atliktas 2013-2015 m. Uhnin vietovejje $\left(51.5833^{\circ} \mathrm{N}, 23.0333^{\circ} \mathrm{E}\right)$, Vidurio Rytų Lenkijoje. Buvo tirta tręšimas įvairiomis normomis (0, 50, 100, 150 ir $200 \mathrm{~kg} \mathrm{ha}^{-1} \mathrm{~N}$ ) azoto trąšų. Eksperimento metu nustatyta, kad skirtingos metų sąlygos turèjo teigiamą įtaką sausujų medžiagų kiekiui stiebagumbiuose bei jų derliui ir minimalią - chlorofilo fluorescencijos bei chlorofilo $a$ kiekiui. Tręšimo ir metų sąveika mažiausią įtaką turèjo bendrajai dispersijai, didžiausią - chlorofilo $b$ kiekiui. Azoto trąšos turèjo mažiausią įtaką chlorofilo fluorescencijos fiziologiniams pokyčiams, tačiau gana didelę sausųjų medžiagų kiekiui stiebagumbiuose ir jų derlingumui. Tręšimas $150 \mathrm{~kg} \mathrm{ha}^{-1} \mathrm{~N}$ palankiai paveikẻ elektronų judejimo srautą, pradedant nuo augalų 6-ojo lapo augimo tarpsnio iki fiziologinès brandos. Taip pat nustatyta, kad tręšimas azotu stimuliuoja saldžiųų bulvių fotosintezès efektyvumą augalų vegetacijos pabaigoje. Didinant azoto normas chlorofilo fluorescencija $\left(\mathrm{F}_{\mathrm{m}}\right)$ mažejo. Reikšmingas fotocheminio efektyvumo (PS) II (Y) padidejjimas ir fluorescencijos koeficiento (qP) mažèjimas vyko iki tręšimo $100 \mathrm{~kg} \mathrm{ha}^{-1} \mathrm{~N}$. Mažiausią chlorofilo fluorescencijos intensyvumą $\left(\mathrm{F}_{0}\right)$, nefotochemį fluorescencijos silpnèjimo koeficientą (qN) ir elektronų judejjimo spartą (ETR) palankiausiai veikè tręšimas $150 \mathrm{~kg} \mathrm{ha}^{-1} \mathrm{~N}$.

Reikšminiai žodžiai: chlorofilas, chlorofilo fluorescencija, Ipomoea batatas, produktyvumas, tręšimas azotu. 